\title{
Human intestinal mucosal mast cells: evaluation of fixation and staining techniques
}

\author{
STEPHAN STROBEL, HUGH RP MILLER, ANNE FERGUSON \\ From the Gastro-Intestinal Unit, Western General Hospital and University of Edinburgh, and Moredun \\ Research Institute, 408 Gilmerton Road, Edinburgh
}

SUMMARY The staining properties of tissue mast cells are influenced by the method of fixation. Differences in fixation and staining techniques may explain the contradictory results in the published reports on the number of human mucosal mast cells (MMC) in the gastrointestinal mucosa in health and disease.

We have examined the influence of fixatives on the staining properties of human MMC in operative biopsy specimens of human jejunum. Specimens were divided into pieces, each of which was fixed in one of the following fixatives: Carnoy's, basic lead acetate (BLA), Baker's, Bouin's, isotonic formol-acetic-acid (IFAA), 10\% neutral buffered formalin, formol sublimate, and formol saline. Thereafter, tissues were paraffin-embedded and $5 \mu \mathrm{m}$ sections were cut and stained with either astra-blue/safranin $\mathrm{pH} 0 \cdot 3$, or toluidine blue $\mathrm{pH} 0 \cdot 5$. Counts of the number of $\mathrm{MMC} / \mathrm{mm}^{2}$ were obtained for each fixation method. The results show a critical influence of the fixative on the number of mast cells indentified after staining. For example with astra-blue/safranin the mean $\mathrm{MMC} / \mathrm{mm}^{2}$ count was 40 in formol-saline-fixed specimens, and 268 in Carnoy's-fixed specimens. In biopsies fixed with formalin-based fixatives, mast cells were more readily stained with toluidine blue. It is recommended that Carnoy's or BLA be used as the fixative for any light microscopic study of human MMC.

The mucosa of the gastrointestinal tract contains many lymphoid cells. These include lymphocytes, plasma cells, macrophages, mast cells and eosinophils. Mucosal mast cells (MMC) and IgE-mediated immune reactions, are of interest not only in view of their established role in parasite immunity, ${ }^{12}$ but also because reaginic hypersensitivity, or other immunological reactions involving mast cells, may be implicated in a range of intestinal hypersensitivity diseases. For clinical diagnosis, and in research studies, various methods are used to stain mast cells in human mucosal biopsies, and such biopsies have generally been fixed in a formalin-based fixative before processing. Yet it is known from studies in animals that staining patterns of MMC are critically dependent upon the fixation technique. In 1966 Enerbäck ${ }^{3}$ showed that the rat small intestine, when fixed in $4 \%$ formaldehyde, appeared to be completely devoid of MMC whereas many such cells could be detected with other fixation methods. We are not aware of a comparable study of the optimal fixation and staining methods for MMC in man. We have therefore carried out an experiment, using operative

Accepted for publication 13 January 1981 intestinal biopsies and a range of commonly used fixatives, to establish whether the method of fixation influences the number of MMC detected in human intestinal mucosa.

\section{Material and methods}

Operative biopsies of normal jejunum were obtained from 13 patients who were undergoing abdominal surgery. In all cases the intestine was incised for resection or for creation of an anastomosis. Diagnoses were pyloric stenosis 4; adenocarcinoma of stomach or colon 3; duodenal ulcer 3 ; gastric ulcer 1; adhesions 1; unexplained abdominal pain 1. Each specimen was rinsed in cold saline and divided into eight pieces which were placed in fixative within 10 min. The period of fixation varied from one to seven days (except for Carnoy's) as indicated below. After fixation the tissues were embedded in paraffin; non-serial sections, $5 \mu \mathrm{m}$ thick, were cut and stained with astra-blue/safranin and with toluidine blue.

FIXATIVES 34

1 Carnoy's fixative $(60 \mathrm{ml}$ absolute ethanol, $30 \mathrm{ml}$ chloroform, $10 \mathrm{ml}$ glacial acetic acid). Mini851 
mum fixation time $2 \mathrm{~h}$.

2 BLA (Mota's basic lead acetate acetic-acid ethanol, $1 \mathrm{~g}$ basic lead acetate, $50 \mathrm{ml}$ ethanol, $50 \mathrm{ml}$ distilled water, $0.5 \mathrm{ml}$ glacial acetic acid). Minimum fixation time $24 \mathrm{~h}$.

3 IFAA (isotonic formol-acetic-acid, $1.5 \%$ formalin (commercially available solution of $40 \mathrm{~g}$ formaldehyde in $100 \mathrm{ml} \mathrm{H}_{2} \mathrm{O}, 0.5 \%$ glacial acetic acid). Minimum fixation time 2 days.

4 Baker's fixative (formalin calcium chloride, $10 \%$ formalin, $2 \%$ calcium chloride in distilled water). Minimum fixation time $24 \mathrm{~h}$.

5 Bouin's fixative $(25 \mathrm{ml}$ formalin, $75 \mathrm{ml}$ saturated picric acid solution, $5 \mathrm{ml}$ glacial acetic acid). Minimum fixation time $24 \mathrm{~h}$.

$610 \%$ buffered formalin $\mathrm{pH} 7.0(10 \mathrm{ml}$ formalin, $90 \mathrm{ml}$ tap water, $0.4 \mathrm{~g} \mathrm{NaH}_{2} \mathrm{PO}_{4} .2 \mathrm{H}_{2} \mathrm{O}$ and $0.65 \mathrm{~g}$ $\mathrm{Na}_{2} \mathrm{HPO}_{4}$ added to give $\mathrm{pH} 7 \cdot 0$ ). Minimum fixation time 7 days.

7 Formol sublimate $(10 \mathrm{ml}$ formalin, $90 \mathrm{ml}$ saturated aqueous mercuric chloride solution). Minimum fixation time $24 \mathrm{~h}$.

8 Formol saline $(10 \mathrm{ml}$ formalin, $90 \mathrm{ml} 0.85 \%$ sodium chloride). Minimum fixation time 7 days.

ST A I N S

\section{Astra-blue/safranin pH $0 \cdot 3^{5}$}

Astra-blue powder $(1.0 \mathrm{~g})$ (Gurr Chemical Ltd, Code Number 2870) was dissolved in $100 \mathrm{ml} 0.7 \mathrm{~N} \mathrm{HCl}$. Concentrated $\mathrm{HCl}$ was added to lower the $\mathrm{pH}$ to 0.3 which gave a final concentration of about $0.8 \mathrm{~N}$.

Sections were stained in $1 \%$ astra-blue solution for $30 \mathrm{~min}$, and washed thereafter for $5-10 \mathrm{~min}$ in $0.7 \mathrm{~N} \mathrm{HCl}$. Counterstaining was achieved by dipping the sections into $0.5 \%$ safranin 0 (Gurr Chemical Ltd, Code Number 27300) in 0.125 $\mathrm{N} \mathrm{HCl}$ for $30 \mathrm{~s}$ or less. Finally the sections were taken through graded alcohols to xylene and mounted in coverbond TM (Harleco-Herstal, Liège, Belgium, Code Number 7886).

\section{Toluidine blue pH $0 \cdot 5^{4}$}

Toluidine blue powder $(0.5 \mathrm{~g})$ (Gurr Chemical, Code Number 29880) was dissolved in $100 \mathrm{ml} 0.5$ $\mathrm{N} \mathrm{HCl}(\mathrm{pH} \mathrm{0.5)}$. The sections were taken to water as above and were stained with this solution for 30 $\mathrm{min}$. They were rinsed in water for $5-10 \mathrm{~min}$, differentiated in $95 \%$ alcohol, and were cleared and mounted as above.

METHOD FOR MAST CELL COUNTS Mast cells were counted in well orientated sections cut perpendicular to the mucosa and in which the muscularis mucosae was intact. Counts were per-

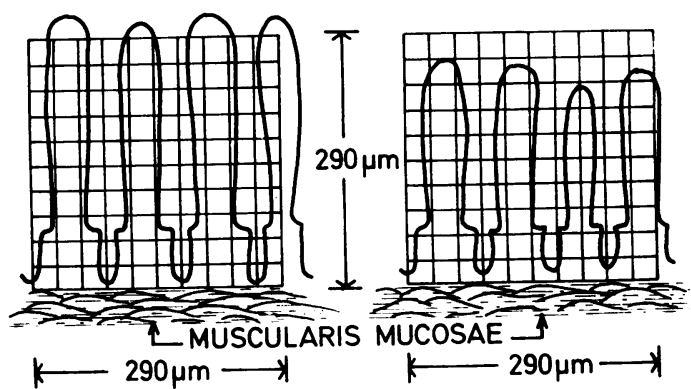

Fig. 1 Counting technique for mucosal mast cells. One edge of the eyepiece graticule is orientated along the muscularis mucosa. The height of mucosa included in the field varies from $80-100 \%$, depending on shrinkage of the specimen. Section thickness $5 \mu \mathrm{m}$. Area of graticule $250 \mu \mathrm{m} \times 290 \mu \mathrm{m}=0.084 \mathrm{~mm}^{2}$.

formed on coded slides on a Leitz Dialux 20 EB microscope (eyepiece $\times 10$, objective $\times 40$ ). A $10 \mathrm{~mm}^{2}$ eyepiece graticule, calibrated against a calibration slide was used. The edge of the graticule was orientated along the muscularis mucosae, at the base of the crypts. The area covered by the square of the graticule comprised $80-100 \%$ of the total depth of the mucosa (from the bottom of the crypt to the tip of the villus) (Fig. 1). On each slide, eight to ten fields $\left(290 \mu \mathrm{m} \times 290 \mu \mathrm{m}\right.$; area $\left.0.084 \mathrm{~mm}^{2}\right)$ were counted and the MMC count per specimen was expressed as $\mathrm{MMC} / \mathrm{mm}^{2}$. No attempt was made to correct for the area covered by epithelium.

STATISTICAL ANALYSIS

Results are expressed as mean $(\overline{\mathrm{x}})$ and standard deviation (SD) or standard error of the mean (SE) and were compared by Student's $t$ test. The reproducibility of duplicate counts on the same slide was assessed by linear regression analysis.

\section{Results}

Of the specimens obtained from the patients, 208 pieces of tissue were available for study, and the orientation of 201 samples was such that enumeration of MMC could be carried out. Mast cells were seen both in the mucosa and submucosa. Those in the submucosa were typical of other connective tissue mast cells and contained many intensely stained granules which frequently obscured the nucleus. The MMC in the mucosa were smaller and contained fewer granules. This difference between mucosal and submucosal mast cells has also been reported in the rat. ${ }^{3}$ Granulated lymphocytes of a type commonly found in rodents 267 were detected with the oil immersion objective $(\times 100)$. They were located intraepithelially in small numbers in many of the 
specimens examined and were unlikely to be confused with the rarer intraepithelial mast cells in the epithelium. Granulated intraepithelial lymphocytes were medium sized, having light, rather featureless cytoplasm which contained smaller and fewer granules than MMC; these were located peripherally along the cell membrane and did not obscure the nucleus. The staining properties of lymphocyte and MMC granules were, however, similar.

There was considerable variation in the background staining of tissues, depending on the type of fixative used (illustrated in Fig. 2) but this was not the reason for the marked differences in MMC counts described below. MMC stained with astrablue/safranin had blue granules against a pale red background. When stained with toluidine blue, the granules were deeply stained with a violet metachromasia against a pale blue background. The background staining in formalin-fixed biopsies was more intense than in tissues fixed in Carnoy's or BLA fixative. In Carnoy's and BLA-fixed tissues, the mast cells were extremely well preserved and could be detected at all levels of the lamina propria, including the villus core (Fig. 2) and, rarely, the crypt epithelium. In tissues fixed in formalin, MMC were predominantly located in the basal mucosa and were poorly preserved, as was evident from the swollen appearance of the cells and from the virtual absence of mast cells in the villus core.

For photographic documentation of MMC, preparations stained with toluidine blue were found to give better black and white contrast than did those stained with astra-blue/safranin.

EVALUATION OF COUNTING TECHNIQUE All MMC counts were made on coded slides with one edge of the graticule orientated along, and covering, a $290 \mu \mathrm{m}$ length of muscularis mucosae. Formalin-based fixatives produced considerable shrinkage of the biopsies and thus the graticule depth consistently included $100 \%$ of mucosal depth in these preparations. In contrast, between 80 and $100 \%$ of the depth of the mucosa was covered by the graticule in tissues preserved in Carnoy's or in BLA (see Fig. 1). A preliminary evaluation of this differential shrinkage effect as a source of error in MMC counts revealed that most MMC were confined to the lower one third of the mucosa. With non-formalin-based fixatives, less than $2 \%$ of MMC in an area of mucosa of $0.084 \mathrm{~mm}^{2}$ would be missed by applying the method described above. Thus this technique is basically a tissue unit counting method as used with minor variations by several investigators $^{8-12}$.

All counts were made by one investigator (SS).

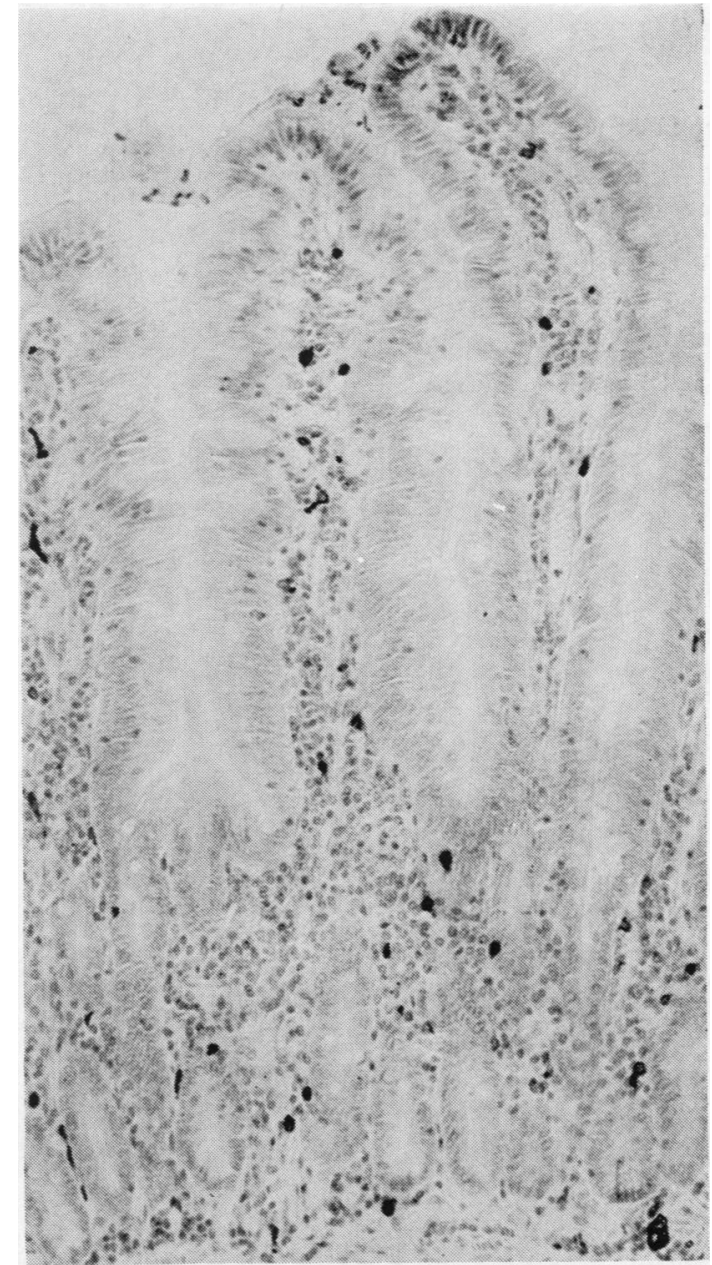

Fig. 2 Illustration of the critical effects of fixative on the staining properties of human mucosal mast cells. An operative biopsy of normal jejunum was fixed in Carnoy's (Figs. 2a, b), Bouin's (Figs, 2c, d), and 10\% buffered formalin (Figs. $2 e, f$ ) tissues were paraffinembedded and $5 \mu \mathrm{m}$ sections were cut and stained with toluidine blue.

Fig. 2a Many mast cells are clearly seen as dark cells against a pale background stain. MMC count: $190 / \mathrm{mm}^{2}$; Carnoy's, toluidine blue $\times 190$.

Duplicate counts in 12 specimens showed a correlation coefficient of $r=0.917(p<0.001)$ by linear regression analysis, confirming the internal consistency and reproducibility of the technique.

\section{MAST CELL COUNTS}

The number of mast cells detected in tissue sections was found to depend critically on the type of 


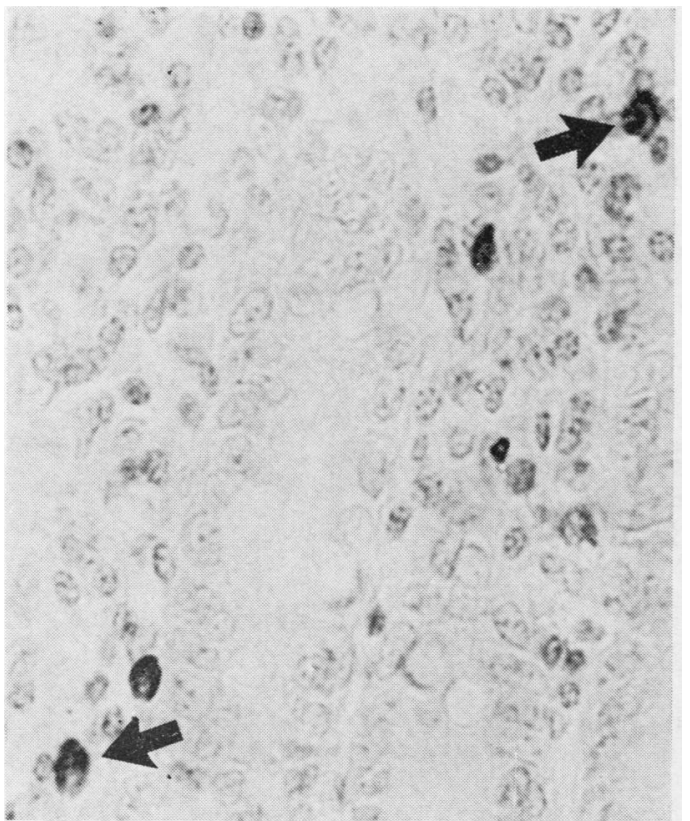

Fig. $2 b \quad$ Higher magnifications $(\times 600)$ demonstrate the typical granular appearance of mast cells and its good preservation (arrow).

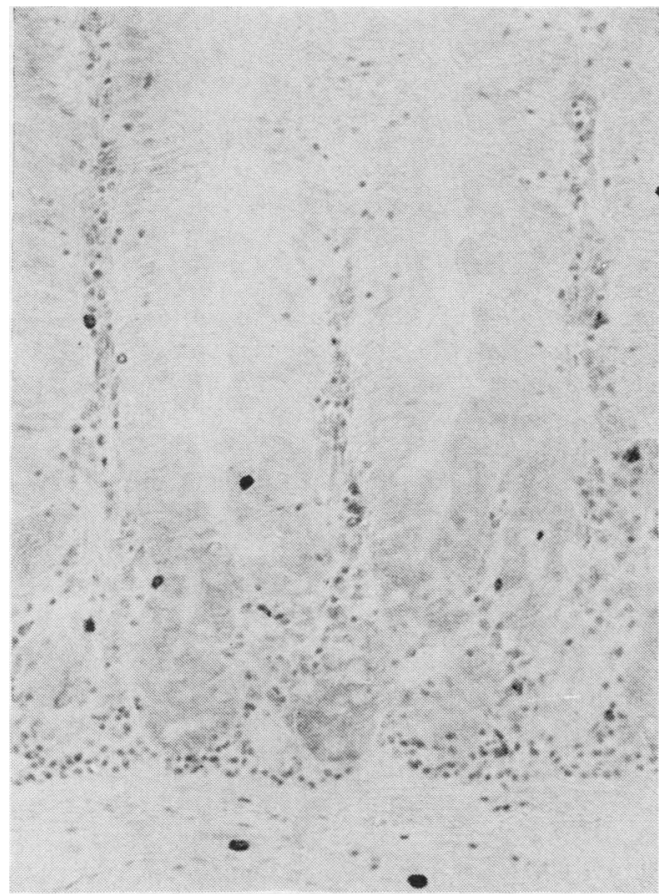

Fig. 2c Some mast cells can be seen in the villus core, and there are well stained mast cells in the submucosa. MMC count: 100/mm ${ }^{2}$; Bouin's, toluidine blue $\times 190$.

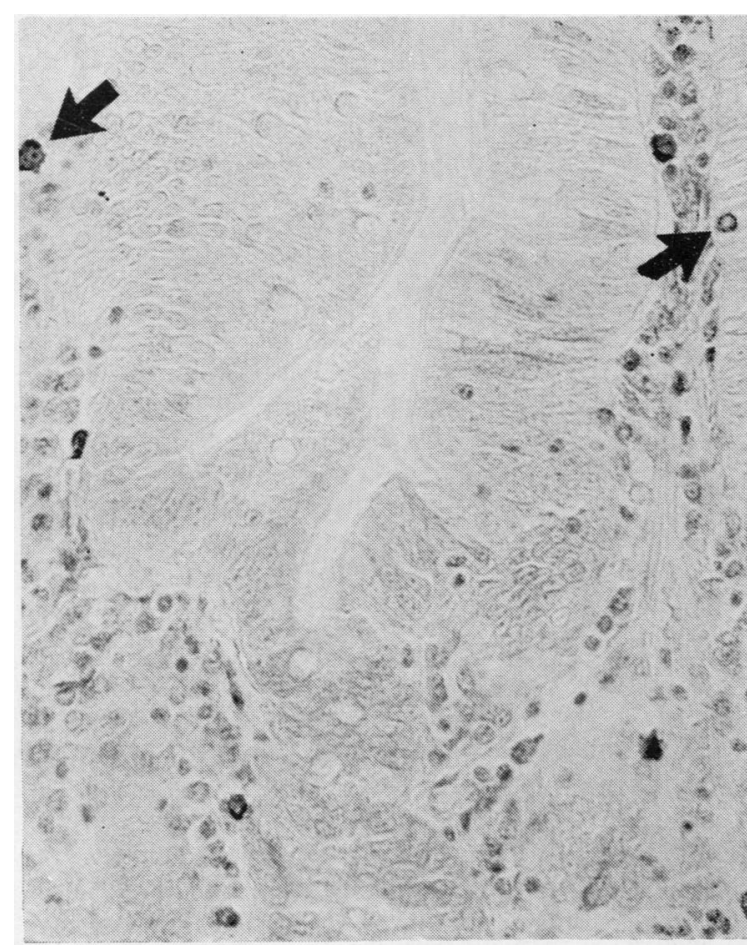

Fig. 2d At higher magnification $(\times 375)$ the granular appearance of $M M C$ and of some intraepithelial cells is noticeable (arrow).

fixative employed. In order to apply statistical analysis to this subjective observation, the counts for each fixative/stain combination made on the 13 biopsies of normal jejunum have been combined, and mean, SD (not shown) and SE calculated. (Thus each group consisted of 11-13 biopsies for each of the 26 fixative/stain combinations.) The results are shown in Fig. 3.

Substantially more MMC were detected in tissues which had been fixed with Carnoy's or with BLA, than in the tissues fixed in formalin-based fixatives. For example, after staining with astra-blue, the mean value for the 13 specimens was $268 \mathrm{MMC} / \mathrm{mm}^{2}$ in Carnoy's fixed tissue, and only $47 \mathrm{MMC} / \mathrm{mm}^{2}$ in biopsies fixed in $10 \%$ buffered formalin $(p<0.001)$. That the pattern was consistent within each biopsy is illustrated in Fig. 4. There were 11 biopsies in which counts for Carnoy's, Bouin's and buffered formalin-fixed preparations were available, and in every case fewer MMC were detected when Bouin's was compared with Carnoy's, and when buffered formalin was compared with Bouin's.

Statistical analysis of the various results is summarised in the legend to Fig. 3. When compared to the $\mathrm{MMC} / \mathrm{mm}^{2}$ in Carnoy's fixed specimens, significantly $(\mathrm{p}<0.001)$ fewer mast cells were 


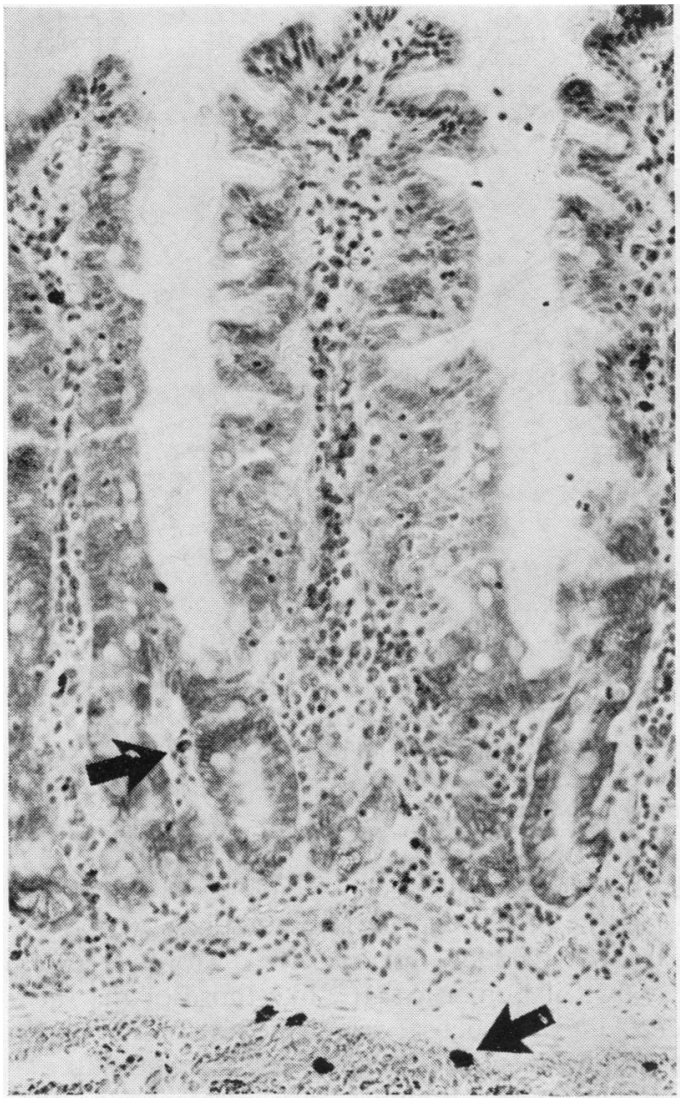

Fig. 2e Only occasional mast cells are found in villus core and around the crypt (arrow), although submucosal mast cells (arrow) are well stained. MMC count:

$68 / \mathrm{mm}^{2} ; 10 \%$ buffered formalin, toluidine blue $\times 190$.

present in samples fixed in any of the formalinbased fixatives. Mast cell counts were comparable whether sections were stained with astra-blue or toluidine blue, except where the tissues were fixed in formalin-based fixatives where counts tended to be lower with astra-blue staining, and this difference was significant $(\mathrm{p}<0.025)$ in the $10 \%$ buffered formalin-fixed tissues.

\section{Discussion}

This study demonstrates unequivocally that the preservation of MMC in human intestinal mucosa is a function of the type of fixative employed. Thus, significantly more MMC were detected after fixation in Carnoy's or BLA than in fixatives containing $10 \%$ formalin. These observations may explain the widely discordant reports of intestinal MMC counts in human disease (Table). ${ }^{13-18}$ Most

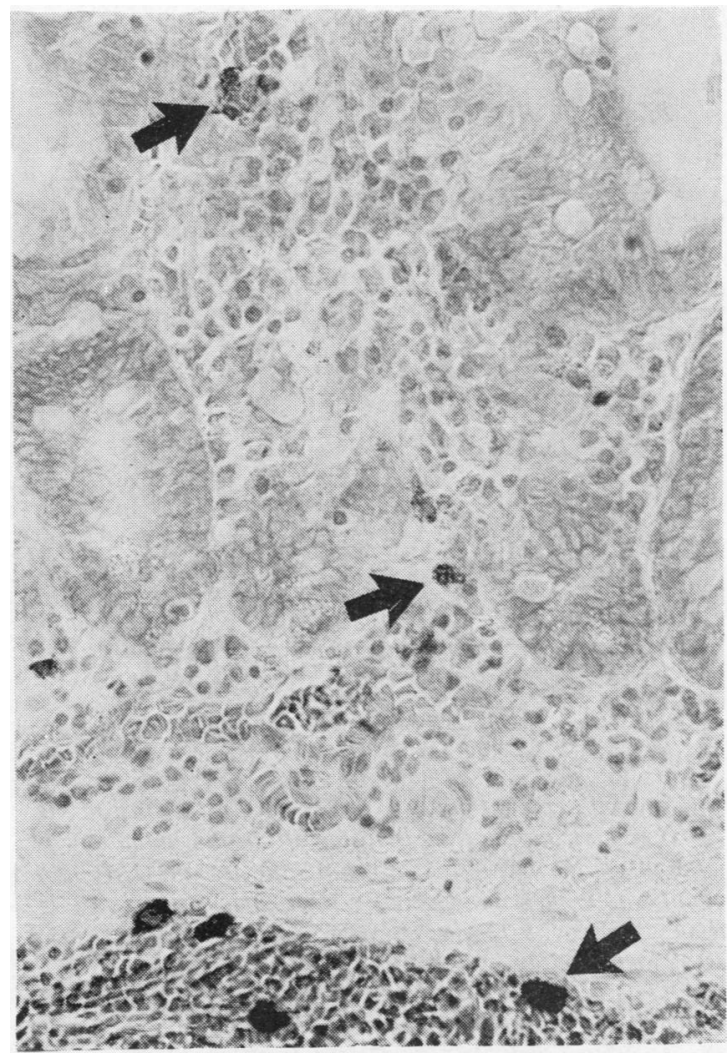

Fig. 2f At higher magnification few poorly preserved MMC (arrow) are demonstrated, whereas the submucosal mast cells are well preserved and stained $\times 375$.

published studies have been performed in formalinfixed preparations, and this study has demonstrated that fivefold higher mast cell counts can be obtained, in normal tissues, if Carnoy's is used as the fixative.

Although the composition of human MMC granules has not been examined in detail they are likely to have many features in common with the granules of rat mucosal mast cells. The latter contain monoamines, ${ }^{13}$ basic protein, ${ }^{1}$ a protease, ${ }^{19}$ and acid mucopolysaccharides (glycosylaminoglycans, GAG). ${ }^{3}$ In the rat, MMC GAG are less strongly sulphated than connective tissue mast cell GAG. 1320

The staining methods used to demonstrate mast cells by light microscopy depend on the affinity of cationic dye for the mast cell granule GAG. Optimal fixation will result in precipitation of GAGs leaving polyanionic sites available for binding of dye. Failure to demonstrate mast cells in fixed tissues may be due either to dissolution of nonprecipitated $\mathrm{GAG}^{3}$ or to blocking of polyanions by cationic 


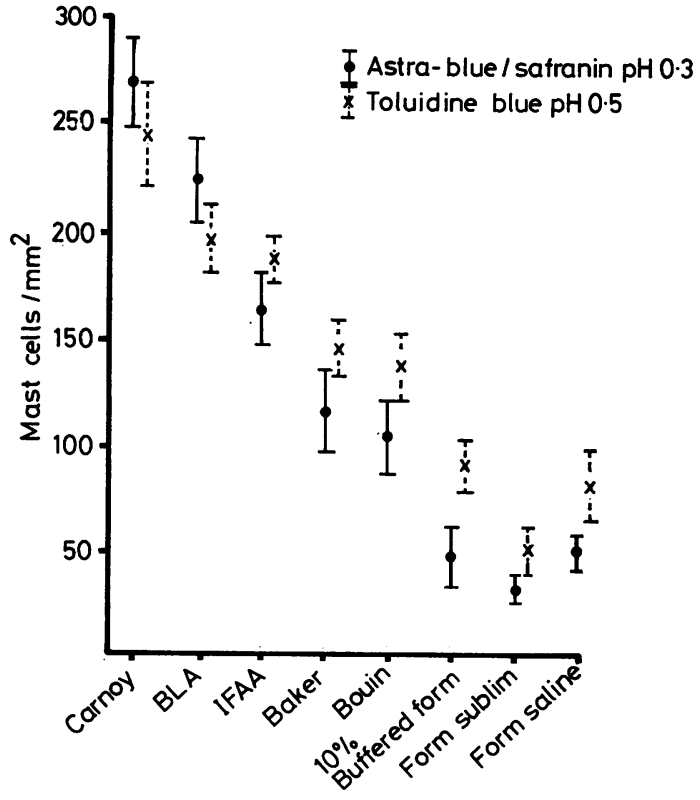

Fig. 3 Influence of eight fixatives and two stains on the $M M C$ count in operative biopsies of normal human jejunum. With astra-blue/safranin stain, mean MMC count was highest for Carnoy's-fixed specimens. In tissues fixed with IFAA, Baker's, Bouin's and the three $10 \%$ formalin based fixatives, MMC counts were significantly lower $(p<0.001)$ than in Carnoy's-fixed tissues. With toluidine blue stain, mean MMC count was again highest in Carnoy's fixed specimens. In tissues fixed with Baker's, Bouin's, and the three $10 \%$ formalin-based fixatives, MMC counts were significantly lower $(p<0.001)$ than in Carnoy's-fixed tissues. With this stain the difference between IFAA-fixed specimens and Carnoy's was significant at $p<0.05$. With astra-blue and toluidine blue stains, MMC counts in BLA-fixed preparations were lower than in Carnoy'sfixed preparations, but the differences were not significant.

Comparison between the two stains showed that values for MMC counts were higher in toluidine blue stained sections, in those specimens which had been fixed in the formalin-based fixatives. This reached significance only for $10 \%$ buffered formalin $(p<0.025)$.

proteins. ${ }^{1}$ Experimental data favour the latter hypothesis since rat mucosal mast cells can be demonstrated in formalin-fixed intestine by the critical electrolyte concentration technique. ${ }^{1}$ Carnoys and lead-based fixatives penetrate tissues rapidly, and precipitate both GAG and proteins; also the acidity of Carnoy's may facilitate ionic linkages between GAG and basic cationic dyes. ${ }^{21}$

In virtually all of the specimens examined, as is illustrated in Fig. 2, submucosal mast cells were found to be much less sensitive to the effects of fixation than were MMC. Such differences between mucosal

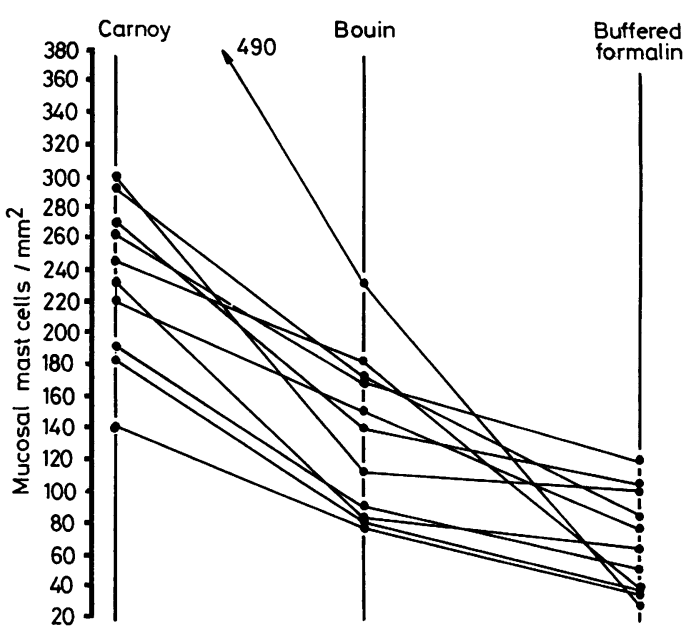

Fig. 4 MMC counts in 11 operative biopsies of normal human jejunum, fixed in Carnoy's, Bouin's, and buffered formalin and stained with toluidine blue. All specimens showed the same pattern, with MMC counts being consistently lower in Bouin's and buffered formalinfixed preparations.

and submucosal mast cells have long been recognised, one of the first reported observations being by Maximow $^{22}$ in 1906 (for review ${ }^{23}$ ). However, it is not known if human MMC, like those of the rat, ${ }^{1}$ differ from submucosal or connective tissue mast cells in their response to amine-releasing stimuli.

Metachromatic granules are present in the cytoplasm of many of the small intestinal intraepithelial lymphocytes of a variety of species. Some authors indeed use the term "granular lymphocyte" to describe the intraepithelial lymphocyte, and it has been suggested that these cells are the precursors of mast cells. ${ }^{7}$ An important finding in our study has been the observation that a small proportion of human mucosal intraepithelial lymphocytes do contain metachromatic granules as has been frequently found in rodents. ${ }^{2} 67$ Judging from their staining properties, the granules of intraepithelial lymphocytes are likely to contain GAG but, when compared with MMC, lymphocytes contain smaller and fewer granules which do not obscure the nucleus. Whether these distinctive populations of granulated lymphocytes in human gut represent, as is postulated for rodents, ${ }^{6} 7$ a bone marrow-derived $T$ cellindependent or a $\mathrm{T}$ cell-dependent subpopulation remains to be established.

Research on MMC in patients will probably be pursued in conditions such as inflammatory bowel disease, allergic intestinal disease and infectious diseases. For such work the pathologist is likely to include counts of eosinophils and of IgE-containing 
Published results of mucosal mast cell counts in human jejunum

\begin{tabular}{|c|c|c|c|c|}
\hline Reference & Tissue preparation & Counting technique & Mast cell count & Diagnosis \\
\hline Selbekk $\mathrm{BH}^{13}$ & $\begin{array}{l}4 \% \text { formaldehyde, } \\
\text { pinacyanol erythrosinate }\end{array}$ & graticule $(320 x)$ & $\begin{array}{l}100 ; \text { range: } \\
10-220 / \mathrm{mm}^{2} \text { (operative) } \\
80 ; \text { range: } \\
10-180 / \mathrm{mm}^{2} \text { (biopsy) }\end{array}$ & normal jejunum \\
\hline Kumar P, et al. ${ }^{14}$ & $\begin{array}{l}\text { fixative not stated } \\
\text { alcian blue }\end{array}$ & $\begin{array}{l}\text { high power field } \\
\text { (size not stated) }\end{array}$ & $\begin{array}{l}\text { 1/field normal } \\
8 / \text { field untreated } \\
\text { 4/field treated }\end{array}$ & coeliac disease \\
\hline Walker-Smith J, et al. ${ }^{13}$ & $\begin{array}{l}\text { formalin } \\
\text { aldehyde fuchsin }\end{array}$ & $\begin{array}{l}\text { computerised } \\
\text { tissue unit count }\end{array}$ & $\begin{array}{l}171,170,80,60 \mathrm{~mm}^{2} \\
\text { prechallenge } \\
190,100,90,50 \mathrm{~mm}^{2} \\
\text { post challenge }\end{array}$ & CMPI* \\
\hline Kingston $\mathrm{D}$, et al..$^{16}$ & $\begin{array}{l}\text { fixative not stated } \\
\text { alcian blue }\end{array}$ & $232 \mu \mathrm{m}$ tissue unit & $\begin{array}{l}3,10,17,3,4 \text { tissue unit } \\
\text { prechallenge } \\
4,9,9,6,4 \text { tissue unit } \\
\text { post challenge }\end{array}$ & CMPI \\
\hline Rohner HG, et al. ${ }^{17}$ & $\begin{array}{l}\text { formalin } \\
\text { Giemsa }\end{array}$ & graticule & $\begin{array}{l}<80 / \mathrm{mm}^{2} \\
>80 / \mathrm{mm}^{2}\end{array}$ & $\begin{array}{l}\text { normal jejunum } \\
\text { systemic mastocytosis }\end{array}$ \\
\hline Dollberg L, et al. ${ }^{18}$ & $\begin{array}{l}\text { Bouin's fixative } \\
\text { astra-blue }\end{array}$ & microscopic field & $\begin{array}{l}6 \cdot 8 \pm 3 \cdot 85 / \text { field } \\
17 \cdot 3 \pm 5 \cdot 33 / \text { field }\end{array}$ & $\begin{array}{l}\text { coeliac disease } \\
\text { normal control }\end{array}$ \\
\hline $\begin{array}{l}\text { Strobel S, et al. } \\
\text { (present study) }\end{array}$ & $\begin{array}{l}\text { Carnoy's fixative } \\
\text { formalin, } \\
\text { astra-blue }\end{array}$ & $\begin{array}{l}\text { graticule }(345 x) \\
290 \mu \mathrm{m} \text { length of side }\end{array}$ & $\begin{array}{l}268 \pm 77 ; \text { range: } \\
140-490 / \mathrm{mm}^{2} \text { (Carnoy's) } \\
47 \pm 40 ; \text { range: }^{ \pm} \text {. } \\
23-138 / \mathrm{mm}^{2} \text { (formalin) }\end{array}$ & $\begin{array}{l}\text { operative specimens } \\
\text { normal jejunum }\end{array}$ \\
\hline
\end{tabular}

*CMPI = cows' milk protein intolerance.

plasma cells-for example, by an immunoperoxidase technique, in the protocol. Carnoy's fixed specimens are unsuitable for the staining of eosinophils by carbolchromotrop $2 \mathrm{R}$, and immunoperoxidase staining techniques are in general optimal in formol saline or formol sublimate-fixed materials. ${ }^{24}$ Thus, if light microscopic evaluation is to be used, there is at the moment no alternative but to divide a biopsy specimen for separate processing for mast cells and for IgE/eosinophil counts.

We recommend that the standard method for processing of human mucosal biopsies to evaluate intestinal MMC should be by the use of Carnoy's or BLA as fixative, and astra-blue/safranin or toluidine blue as stain.

Not all commercially available batches of astrablue dye are suitable for staining of mucosal mast cells. We have obtained excellent results with Gurr's astra-blue (which is unfortunately no longer available). Similar good results have been obtained with astra-blue from E Merck, Darmstadt, FR Germany.

We gratefully acknowledge the skilful technical assistance of Francis Donnelly, John Huntley, and Graham Wallace. We thank the surgeons of the Western General Hospital for their collaboration during this study, Mr James Paul for help with the photography, the Medical Illustration Department of the Western General Hospital for providing the graphs and Mrs Doreen Orr who has prepared the manuscript. Dr Strobel is in receipt of a grant from the Deutsche Forschungsgemeinschaft DFG 210/1 STR.

\section{References}

${ }^{1}$ Miller HRP, Walshaw $R$. Immune reactions in mucous membranes. IV Histochemistry of intestinal mast cells during helminth expulsion in the rat. Am $J$ Pathol 1972;69:195-206.

${ }^{2}$ Miller HRP. The structure, origin and function of mucosal mast cells. Biol Cellulaire 1980;39:229-232.

${ }^{3}$ Enerbäck L. Mast cells in rat gastrointestinal mucosa. 1 Effects of fixation. Acta Pathol Microbiol Scand 1966;66:303-12.

${ }^{4}$ Pearse AGE. Histochemistry. Theoretical and applied. Vols. 1, 2. London: Churchill Livingstone, 1972.

${ }^{5}$ Bloom G, Kelly IW. The copper phthalocyanin dye 'Astrablau' and its staining properties, especially the staining of mast cells. Histochemie 1960;2:48-57.

6 Mayrhofer G. Thymus-dependent and thymus independent subpopulations of intestinal intraepithelial lymphocytes: a granular subpopulation of probable bone marrow origin and relationship to mucosal mast cells. Blood $1980 ; 55: 532-5$.

${ }^{7}$ Guy-Grand D, Griscelli C, Vassalli P. The mouse gut T lymphocyte, a novel type of $T$ cell. Nature, origin and traffic in mice in normal and graft-versus-host conditions. J Exp Med 1978;148:1661-77.

${ }^{8}$ Brandtzaeg P, Baklien K, Fausa O, Hoel PS. Immunohistochemical characteristics of local immunoglobulin formation in ulcerative colitis. Gastroenterology 1974; 66:1123-36.

${ }^{9}$ Batcup G, Spitz L. A histopathological study of gastric mucosal biopsies in infantile hypertrophic pyloric stenosis. J Clin Pathol 1979;32:625-8.

10 Takahashi T, Shimazu H, Yamagishi T, Masayoshi T. G-cell populations in resected stomachs from gastric and duodenal ulcer patients. Gastroenterology 1980; 78:498-504.

11 Sjölund K, Alumets I, Berg NO, Håkanson R, Sundler F. Duodenal endocrine cells in adult coeliac disease. Gut 1979;20:547-52.

12 Selbekk BH, Flaten O, Hanssen LE. The in vitro effect of neurotensin on human jejunal mast cells. Scand $J$ Gastroenterol 1980;15:457-60. 
${ }^{13}$ Selbekk BH. Mast cell reactions in human jejunal mucosa in vitro. In: Edwards AM, Pepys J, eds. The mast cell. Tunbridge Wells: Pitman Medical, 1979:710-5.

1 Kumar P, O'Donoghue DP, Lancaster-Smith M. Cellular changes in the jejunal mucosa following the reintroduction of gluten in treated coeliac disease. In: Edwards AM, Pepys J, eds. The mast cell. Tunbridge Wells: Pitman Medical, 1979:647-50.

${ }_{15}$ Walker-Smith J, Phillips A. The pathology of gastrointestinal allergy. In: Edwards AM, Pepys J, eds. The mast cell. Tunbridge Wells: Pitman Medical, 1979: 629-37.

${ }^{16}$ Kingston D, Pearson J, Shiner M. The mast cell in gastrointestinal allergy. In: Edwards AM, Pepys J, eds. The mast cell. Tunbridge Wells: Pitman Medical, 1979: 394-405.

17 Rohner HG, Klingmüller G, Rodermund OE, Leisler LS. Mastocytosis. In: Edwards AM, Pepys J, eds. The mast cell. Tunbridge Wells: Pitman Medical, 1979:110-4.

${ }^{18}$ Dollberg L, Gurevitz M, Freier S. Gastrointestinal mast cells in health, and in coeliac disease and other conditions. Arch Dis Child 1980;55:702-5.

19 Woodbury RG, Gruzenski GM, Lagunoff D. Immunofluorescent localisation of a serum protease in rat small intestine. Proc Natl Acad Sci USA 1978;75:2785-9.

20 Tas J, Berndsen RG. Does heparin occur in mucosal mast cells of the rat small intestine? J Histochem Cytochem 1977;25:1058-62.

${ }^{21}$ Uvnäs B. Åborg CH, Bergendorf A. Storage of histamine in mast cells. Evidence for an ionic binding of histamine to protein carboxyls in the granule heparin-protein complex. Acta Physiol Scand 1970;78:suppl 336:3-26.

${ }^{22}$ Maximow A. Über die Zellformen des lockeren Bindegewebes. Archiv für Mikrobiologie und Anatomie 1906; 67:680-757.

${ }^{23}$ Michels NA. The mast cells. In: Downey H, ed. Handbook of hematology. New York: PB Hoeber Inc, 1938:235-372.

${ }^{24}$ Piris J, Thomas ND. A quantitative study of the influence of fixation on immunoperoxidase staining of rectal mucosal plasma cells. $J$ Clin Pathol 1980;33:361-4.

Requests for reprints to: Dr Stephan Strobel, GastroIntestinal Unit, Western General Hospital, Crewe Road, Edinburgh EH4 2XU, Scotland. 